\title{
The Emerging Urban Co-Operative Banks (Ucbs) In India: Problems and Prospects
}

\author{
${ }^{1}$ Dr.K.V.S.N Jawahar Babu, ${ }^{2}$ B.Muniraja Selkhar \\ ${ }^{1}$ Professor, KMM Institute of Technology\& Science, Tirupati. \\ ${ }^{2}$ Assistant Professor, KMM Institute of Postgraduate Studies, Tirupati.
}

\begin{abstract}
Urban Co-operative banking Sector is an important constituent of Multi Agency banking system operation in the country. These institutions play an important role in the economic enlistment of lower and middle-income group of persons. The Reserve Bank of India in its annual report on trends and progress in banking states that urban banks are important purveyors of credit to small borrowers and to weak sections of the society but is not coming out with any supportive policies that will strengthen the role of UCBs.
\end{abstract}

\section{Urban Co-operative Banks}

\section{Introduction:}

The term Urban Co-operative Banks (UCBs), though not formally defined, refers to primary cooperative banks located in urban and semi-urban areas. These banks, till 1996, were allowed to lend money only for non-agricultural purposes. This distinction does not hold today. These banks were traditionally centered on communities, localities, work place groups. They essentially lend to small borrowers and businesses. Today, their scope of operations has widened considerably. Urban cooperative banks were set up with the objective of promoting sustainable banking practices amongst a relatively specific target clientele viz., the middle income strata of the urban population. They were brought under the regulatory ambit of the Reserve bank by extending certain provisions of the banking regulation act, 1949, effective from march 1, 1966.

\section{Background of UCBs}

The origins of the urban co-operative banking movement in India can be traced to the close of nineteenth century. Inspired by the success of the experiments related to the cooperative movement in Britain and the co-operative credit movement in Germany, such societies were set up in India. Co-operative societies are based on the principles of cooperation, mutual help, democratic decision making, and open membership. Cooperatives represented a new and alternative approach to organization as against proprietary firms, partnership firms, and joint stock companies which represent the dominant form of commercial organization. They mainly rely upon deposits from members and non-members and in case of need, they get finance from either the district central co-operative bank to which they are affiliated or from the apex co-operative bank if they work in big cities where the apex bank has its Head Office. They provide credit to small scale industrialists, salaried employees, and other urban and semi-urban residents. Co operative Banks in India are registered under the Co-operative Societies Act. The cooperative bank is also regulated by the RBI. They are governed by the Banking Regulations Act 1949 and Banking Laws (Co-operative Societies) Act, 1965. A co-operative bank is defined as "a financial entity which belongs to its members, who are at the same time the owners and the customers of their bank. The term Urban Cooperative Banks (UCBs), although not formally defined, refers to the primary cooperative banks located in urban and semi-urban areas. These banks, until 1996, were allowed to lend money only to non-agricultural purposes. This distinction remains today. These banks have traditionally been around communities, localities working out in essence, loans to small borrowers and businesses. Today their scope of operation has expanded considerably.

\author{
Status of UCBs in India: \\ Total Number of Banks in India 1770 \\ Total Deposits Rs.1, 12,000 crs \\ Total Advances Rs. 78,000 crs. \\ Total No. of scheduled banks in India 53 \\ Total No.of Mahila Banks 139 \\ Total No. of Mahila Banks in Mah. 27 \\ Total No.of 1 Unit Banks 900 \\ Salary Earner Banks 24
}

Indian Banking system is on its sound footing UCBs in India are playing major role in servicing rural economy and there is no need to worry as evident from following data regarding UCBs in India. 
Total deposits of scheduled banks Rs. $51,173 \mathrm{crs}$ (42\% of total deposits of UCBs)

Total advances scheduled banks Rs. 32, 884 crs.

Gradation of Banks all India level

Grade-I Banks 690

Grade-II 430

Grade-III 390

Grade-IV 260

With the onset of liberalization, Co-operative banks in India are under pressure to change the ways in which they do business. They now face an increasingly competitive environment not only from banks but also from non-bank financial institutions. Explosive growth in IT has changed the way individuals interact with banks and the way banks respond. In the changed scenario, success will depend on the ability of banks to leverage the human potential and capabilities, Marketing of Banking products, G-sec Market, Customer value added services, competitive pricing of deposits and advances, good corporate governance, information \& Technology.

Co-operative banking - The challenges ahead In recent years, there has been a considerable widening and deepening of the Indian financial system, of which banking is a significant component. With greater liberalization, the financial system has come to play a much larger role in the allocation of resources than in the past and its role in future can be expected to be much larger than at present. The growing role of the financial sector in the allocation of resources has significant potential advantages for the efficiency with which our economy functions.

Net profits of UCBs improved in 2010-11 as compared to the previous year owing to higher growth of their total income. But the gross as well as net NPA ratio of UCB sector declined.

The following areas required to take certain measures to be strengthened

- The pattern of resources of Urban cooperative banks(owned funds, deposits, and borrowings)

- The deployment of resources

- The management and supervision

- The role of UCBs in the financial system

- The regulatory framework for cooperatives

The following measures

- $\quad$ Strengthening of regulatory and supervisory framework

- Enhancing capital adequacy standards

- Introducing stringent licensing norms for new entrants into the sector

- Enabling legal amendments and

- Corporate governance measures need to be given very close attending

\section{Review of Growth of Urban Co-operative Banking Sector}

While reviewing the progress made by the urban co-operative banks during the last 10 years, it was observed that the performance has by and large been satisfactory (Table- 2.1). Though there has been reduction in the number of UCBs from 2004 onwards, the total banking business (deposits plus advances) of UCBs has shown steady increase signifying that the banks have been able to garner more business.

\begin{tabular}{|c|c|c|c|}
\hline \multicolumn{4}{|c|}{$\begin{array}{l}\text { Table- 2.1: Performance of UCBs - Deposits and } \\
\text { Advances }\end{array}$} \\
\hline $\begin{array}{c}\text { As on } \\
\text { March 31 }\end{array}$ & $\begin{array}{l}\text { No. of } \\
\text { UCBs }\end{array}$ & \begin{tabular}{|l|} 
Deposits \\
( Crore)
\end{tabular} & $\begin{array}{c}\text { Advances } \\
\text { ('Crore) }\end{array}$ \\
\hline 2001 & 1618 & \begin{tabular}{|l|}
80840 \\
\end{tabular} & 54389 \\
\hline 2002 & 1854 & 93069 & 62060 \\
\hline 2003 & 1941 & 101546 & 64880 \\
\hline 2004 & 1926 & 110256 & (67930 \\
\hline 2005 & $\begin{array}{ll}1872 \\
\end{array}$ & $\begin{array}{ll}105021 \\
\end{array}$ & $\begin{array}{l}66874 \\
\end{array}$ \\
\hline 2006 & 21853 & $\begin{array}{ll}114060 \\
\end{array}$ & $\begin{array}{l}71641 \\
\end{array}$ \\
\hline 2007 & $\begin{array}{l}1813 \\
\end{array}$ & 121391 & $\begin{array}{l}79733 \\
\end{array}$ \\
\hline 2008 & 1770 & 138496 & 88981 \\
\hline 2009 & 1721 & 158733 & 97918 \\
\hline 2010 & 1674 & 182862 & 110303 \\
\hline 2011 & 1645 & 209949 & 135104 \\
\hline
\end{tabular}




\begin{tabular}{|c|c|c|c|c|c|c|}
\hline \multicolumn{7}{|c|}{$\begin{array}{c}\text { Table- 2.4: Return on Assets and Net Interest Margin - } \\
\text { Scheduled Commercial Banks (SCBs) vis-à-vis Urban } \\
\text { Co-operative Banks (UCBs) } \\
\end{array}$} \\
\hline \multicolumn{7}{|c|}{ (In Percentage) } \\
\hline \multirow{2}{*}{$\begin{array}{c}\text { Year } \\
\text { ende } \\
\text { d } \\
\text { 31st } \\
\text { Marc } \\
\text { h }\end{array}$} & \multicolumn{2}{|c|}{\begin{tabular}{||c||} 
All \\
SCBs $($ Exclu \\
ding \\
Regional \\
Rural \\
Banks $)$ \\
\end{tabular}} & \multicolumn{2}{|c|}{$\begin{array}{l}\text { All } \\
\text { Scheduled } \\
\text { UCBs }\end{array}$} & \multicolumn{2}{|c|}{ All UCBs } \\
\hline & \begin{tabular}{|c|} 
Retur \\
n on \\
Asset \\
s
\end{tabular} & \begin{tabular}{|c||} 
Net \\
Intere \\
st \\
Margi \\
n
\end{tabular} & \begin{tabular}{c||} 
Retur \\
n on \\
Assets
\end{tabular} & \begin{tabular}{c|} 
Net \\
Intere \\
st \\
Margi \\
n
\end{tabular} & $\begin{array}{c}\text { Retur } \\
\text { n on } \\
\text { Assets }\end{array}$ & $\begin{array}{l}\text { Net Interest } \\
\text { Margin }\end{array}$ \\
\hline 2005 & 0.97 & 3.08 & 0.47 & 2.03 & NA & \\
\hline 2006 & 0.96 & 3.04 & 0.85 & 2.31 & NA & NA \\
\hline 2007 & 1.05 & 2.86 & 0.74 & 2.30 & 0.75 & 2.8 \\
\hline 2008 & 1.12 & 2.58 & 1.24 & 2.76 & 0.89 & 2.8 \\
\hline 2009 & 1.13 & 2.62 & 1.07 & 2.92 & 0.82 & \\
\hline 2010 & 1.05 & 2.55 & 0.68 & 2.48 & 0.68 & 2.85 \\
\hline \multicolumn{7}{|c|}{$\begin{array}{c}\text { Source: Report on Trend and Progress of Banking in India } \\
\text { Return on Assets = Net Profits/ Average Assets } \\
\text { Net Interest Margin = Net Interest Income (i.e. Interest } \\
\text { Income - Interest Expenses) / Average } \\
\text { Assets }\end{array}$} \\
\hline
\end{tabular}

The performance of the UCB sector other than in the area of market share is comparable with the performance of the Scheduled Commercial Banks (Table- 2.4). The Net Interest Margin (NIM) of the UCB Sector is slightly better than that of the Scheduled Commercial Banks. But the Return on Assets (RoA) is significantly low. The low Return on Assets could be probably due to the restricted earning avenues available to the sector and consequently the less diversified activities undertaken by them. Though the cost of deposits of the UCB sector is generally high, the NIM and RoA of UCBs is not significantly lower than as compared with other groups in the banking industry.

\section{Market Share of Urban Co-operative Banks in Total Banking Sector}

The business growth of UCBs was not, however, commensurate with the overall growth in the banking sector. There has been a gradual fall of the share of UCBs' business in the overall business of the banking sector (Table-2.2).Despite the presence of large number of UCBs, their share in the total deposits and advances of the banking sector is insignificant and the share is reduced year after year. From the market share of 6.3 per cent as on March 31, 2001, it had reduced to 3.5 per cent as on March 31, 2010.This reflects to a large extent the effect of the policy of not permitting UCBs, including the healthy and well managed ones, to open new branches for six years contributing thereby to their inability to garner their share in the growing economy.

\begin{tabular}{|c|c|c|c|c|}
\hline \multicolumn{5}{|c|}{$\begin{array}{c}\text { Table- 2.2: Market Share of Urban Co-operative Banks in } \\
\text { Banking Business in Banking Sector }\end{array}$} \\
\hline \multicolumn{5}{|c|}{ (In Percentage) } \\
\hline $\begin{array}{c}\text { As on } \\
\text { March } 31 \\
\end{array}$ & UCBs & $\begin{array}{l}\text { DCCBs \& } \\
\text { State CBs }\end{array}$ & RRBs & $\begin{array}{c}\text { Commercial } \\
\text { Banks }\end{array}$ \\
\hline 2001 & 6.3 & 7.2 & 2.9 & 83.6 \\
\hline 2002 & 6.4 & 7.2 & 3.0 & 83.4 \\
\hline 2003 & 6.3 & 7.0 & 3.0 & 83.7 \\
\hline 2004 & 5.8 & 6.6 & 3.1 & 84.5 \\
\hline 2005 & 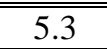 & 6.3 & 3.1 & 85.3 \\
\hline 2006 & 4.6 & 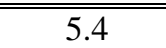 & 2.9 & 87.2 \\
\hline
\end{tabular}




\begin{tabular}{|l||l||l||l||l||}
\hline \hline 2007 & 4.0 & 4.7 & 2.7 & 88.6 \\
\hline \hline 2008 & 3.7 & 4.1 & 2.7 & 89.5 \\
\hline \hline 2009 & 3.4 & 3.9 & 2.6 & 90.1 \\
\hline \hline 2010 & 3.5 & 3.7 & 2.7 & 90.1 \\
\hline
\end{tabular}

\begin{tabular}{|c|c|c|c|}
\hline \multicolumn{4}{|c|}{$\begin{array}{c}\text { Table- 2.3: Market share of Urban Co-operative Banks in } \\
\text { Banking Sector as on March 31, } 2010\end{array}$} \\
\hline $\begin{array}{c}\begin{array}{c}\text { Urban Co- } \\
\text { operative } \\
\text { Banks }\end{array} \\
\end{array}$ & $\begin{array}{c}\text { Rural Co- } \\
\text { operative } \\
\text { Banks } \\
\end{array}$ & $\begin{array}{c}\text { Regional } \\
\text { Rural } \\
\text { Banks }\end{array}$ & $\begin{array}{c}\text { Scheduled } \\
\text { Commercial } \\
\text { Banks }\end{array}$ \\
\hline 1674 Banks & 401 Banks & 82 Banks & 83 Banks \\
\hline \multicolumn{4}{|c|}{ Share in Total Deposits (In \%) } \\
\hline 3.5 & 3.7 & 2.7 & 90.1 \\
\hline \multicolumn{4}{|c|}{ Share in Total Loans and Advances (In \%) } \\
\hline 2.9 & 3.8 & 2.1 & 91.2 \\
\hline
\end{tabular}

It may be observed from the Table-2.3 that despite the fact that the UCB sector has the maximum number of entities as compared to any other group, its market share continues to be meager. This is to be seen in the light of the fact that almost half of the UCBs are unit banks and the total number of branches of the 1674 UCBs as at March 31, 2010 is around 7900 branches as against over 77000 branches of just 83 scheduled commercial banks. Another reason may be that due to the poor capital base of UCBs, coupled with individual and group credit exposure ceilings they are not in a position to lend high value advances. The other reason could be that the clientele of these banks is mainly confined to the lower and middle strata of the society.

\section{- Problems}

Major Problems faced on the UCBs relate to the following aspects:

1. Restrictions relating to share capital.

2. Automatic conversion of credit societies.

3. Dual control and regulations by the RBI and respective state governments on UCB leads to delay and difficulties.

4. Other problems like lack of professionalism, unsatisfactory etc.,

- Acciditing standards connected lending, loans level of technology etc. Suggestions:

- Licensing Policy should be transparent, precise and simple

- Corporate governance is essential for the effective functioning of any financial organization. The UCBs appointed directors in the board should require suitable professional qualifications, experience and they should not have any relationship with other banks.

- In addition to its own funds, the ucbs should generate funds from outsources

- Ucbs should make changes in their regulatory frame work for strengthening recovery mechanism

- Ucbs should maintain computerised reporting system for ready information and competing the commercial banks.

- Ucbs should ready for doing functions of modern banks like commercial banks for increasing their income sources

\section{Conclusion}

Presently, the UCBs occupy an important place in the Indian Financial system. However the ucbs strengthen their uniqueness and growth in the banking industry and it is required to take certain measures like for strengthening the ucbs sector sustenance of its growth is attendant to Professionalization of its management, inculcating good corporate governance, technology absorption and scrupulous adherence to regulatory framework. Let us hope that the urban cooperative banking sector will learn from its past experiences and adjust to new realities since banking is risky business. In future the urban cooperative banks are ready to face many challenges in the competitive environment of both Public and Private sector banks expansion activities both vertically and horizontally. 


\section{References:}

[1]. Report of the Expert committee on Licensing of New Urban Co-Operative Banks 2011

[2]. Report of the committee on UCBs, R.B.I., Bombay, 1979

[3]. Dr. P. Payalvannan Structural Reforms-implications on UCB's, Journal cooperative perspective Jan-June -1997.

[4]. R.B.I Report

[5]. Jagadiesh Capoor UCB's Problems and Prospectus. Journal Urban Credit June- 2000.

[6]. Mukunda. M. Chikale UCB's Mergers. Journal-The Chartered Accountant April- 2005.

[7]. Dr. M. Mohsim Khan Impact of globalization on Indian Banking Industry.Journal-Banking Finance-2004

[8]. G.L. Pai, (1990), "Urban Cooperative Banks and Priority Sector Advances", Urban Credit,

[9]. NFUCB, New Delhi 1990, pp. 18-21.

[10]. AJRBF, Volume 2, Issue 5 (May, 2012) ISSN: 2249-7323, Journal of Asian Research Consortium 23

[11]. http://www.aijsh.org

[12]. Eric Girardin and Xie Ping (1997) "Urban Credit Co-Operatives In China "OECD Development Centre, Working Paper No. 125, August

[13]. 3. Bhaskaran R and Praful Josh P (2000), "Non Performing Assets (NPAs) in Co-operative

[14]. Rural Financial System: A major challenge to rural development”, BIRD’s Eye View Dec.2000.

[15]. Jain (2001), “Comparative study of performance of District Central Co-operative Banks

[16]. (DCCBs) of Western India i.e. Maharashtra, Gujarat \& Rajasthan for the year 1999-2000 from the point of view of net profit/loss", NAFSCOB Bulletin, April-June 2001.

[17]. Dutta Uttam and Basak Amit (2008), "Appraisal of financial performance of Urban co- operative banks- a case study." The Management Accountant, March, 2008, 170-174.

[18]. Arvind G. Deshpande, Chief Executive \& Secretary, The Maharashtra Urban Co-operative Banks Federation Ltd; Mumbai

[19]. Sami Uddin \& Mahfoozur Rahman, Co-operative Sector in India, S. Chand \& Co. New Delhi, 1983,

[20]. Dr. Mamoria, C.B. Rural credit and agricultural co-operation in India, Kitab Mahal, Allahabad, 1983,

[21]. Government of India, "Report of the study group on Credit Co-operatives in the nonagricultural sectors", New Delhi, 1963,

[22]. Nakkiran, S. Urban Co-operative Bank in India, Rainbow Publications, Coimbatore, 1982.

[23]. Indian Banks Association. 